УДК 378.147

DOI:

Ірина Гуменюк, кандидат філологічних наук, дочент кафедри педагогіки початкової освіти

ДВНЗ “Прикарпатський національний університет імені Василя Стефаника"

\title{
НАВЧАЛЬНО-МЕТОДИЧНЕ ЗАБЕЗПЕЧЕННЯ УКРАЇНСЬКОЇ МОВИ ЗА ПРОФЕСІЙНИМ СПРЯМУВАННЯМ: ВЕКТОР ПРОФІЛЬНОЇ АДАПТАЦІї
}

У статті здійснено аналіз сучасних підручників і посібників для студентів педагогічних закладів вищоі освіти. Акиентовано увагу на показниках змістового забезпечення дисиипліни відповідно до робочої програми, актуальності та новизні вміщеної інформачії, адекватності практичного блоку теоретичному наповненню, реалізачї компетентнісної парадигми навчання, засобах профілізації базового матеріалу. Визначено проблемні аспекти змістової організації видань, щэо відображають актуальні питання методики навчання курсу.

Ключові слова: оптимізація навчання; профілізація; компетентнісна парадигма; освітня програма. Jim. 16.

Iryna Humeniuk, Ph.D.(Philology), Associate Professor of the Pedagogy of Primary School Department, SHEI "Vasyl Stefanyk Precarpathian National University"

\section{EDUCATIONALAND METHODICAL SUPPORT OF UKRAINIAN LANGUAGE FOR PROFESSIONAL PURPOSES: THE VECTOR OF PROFESSIONALADAPTATION}

The article determines the levels of implementation of programmatic and methodical documents, which ensure the quality of the educational process. On the basis of analysis of the main approaches, a definition of the "educational and methodical support of Ukrainian Language for Professional Purposes" concept has been formulated. The author emphasizes the competence approach to its formation.

An analysis of modern textbooks and manuals on the Ukrainian Language for Professional Purposes course for students of pedagogical institutions of higher education has been conducted in view of their professional adaptation. An attention has been focused on the indicators of contentual support for the discipline according to the work programme, the relevance and novelty of the contained information, conformity of the practical part with the theoretical one, implementation of the competence paradigm of teaching, and the means of professional adaptation of the fundamental material. The specificity of certain editions is the divide between the directions of working within a single topic. This cannot ensure the formation of the necessary competences and achievement of the planned results of teaching, since it does not permit establishing the interconnection between language phenomena and the real process of their functioning in professional speech.

The problematic aspects of contentual organisation of manuals, which show the relevant issues in the methodology of teaching of the course, have been determined. It has been ascertained that the content of the analysed textbooks depicts the methodical search for the ways of balancing the linguistic and professional communicative parts in the structure of Ukrainian Language for Professional Purposes. The effective formation of the professional and communicative skills in the spoken and written forms cannot take place without consideration of the level of the linguistic competence of students. The ways of solving the problematic situation through implementation of specific organisational and methodical measures have been proposed. The issues of universality of the content and, occasionally, the formal professional adaptation, which does not have a real impact on the ways and means of implementation of the determined aims and achievement of the expected results, remain unsolved in the modern textbooks and manuals on the analysed course.

Keywords: optimisation of teaching; professional adaptation; competence paradigm; an educational programme.

П

остановка проблеми. Основне завдання педагогічного працівника будь-якого закладу освіти цілеспрямоване створення і вдосконалення методичної системи за своїм напрямом роботи, яка б максимально забезпечувала якість освітнього процесу. Матеріальним втіленням такої діяльності виступає певна сукупність програмнометодичних документів, за якими можна вивчити та відтворити методичну систему. Їх призначення в сфері освіти досить широке і піддається визначенню за трьома рівнями: 1) реалізація методичних напрацювань у сфері діяльності їх автора; 2) використання методичних розробок 


\section{НАВЧАЛЬНО-МЕТОДИЧНЕ ЗАБЕЗПЕЧЕННЯ УКРАЇНСЬКОӤ МОВИЗА ПРОФЕСІЙНИМ СПРЯМУВАННЯМ: ВЕКТОР ПРОФІЛЬНОӤ АДАПТАЦІЇ}

здобувачами освіти; 3 ) прикладні аспекти застосування методичних здобутків у загальнонаціональному та світовому масштабах.

Аналіз останніх досліджень і публікацій. Різноманітність трактувань поняття навчальнометодичного та науково-методичного забезпечення зумовлена варіативністю підходів до їх розуміння. Так, позиція Н. Хабарової ілюструє особистісно-діяльнісний підхід, визначаючи науково-методичне забезпечення як забезпечення системи освіти методологічними, дидактичними і методичними розробками, які відповідають вимогам сучасної педагогічної теорії і практики [12]. С. Вітвицька структурує науково-методичне забезпечення педагогічної підготовки магістрів [3]. Науково-методичне забезпечення як педагогічний процес i педагогічний результат розглядають А. Чертопятова і О. Ракова, зазначаючи, що з погляду педагогічного процесу - це розробка оптимального навчально-методичного комплексу дисципліни, необхідного для ефективної організації освітнього процесу. Науково-методичне забезпечення як педагогічний результат авторки трактують через поєднання науково-методичних i навчально-методичних матеріалів, що включають робочу програму курсу, навчальну літературу, методичні матеріали, форми, методи і засоби навчання, засоби контролю і оцінки [13]. Для нашого дослідження актуальним вбачаємо компетентнісний підхід до формування навчальнометодичного забезпечення дисципліни "Українська мова за професійним спрямуванням" (УМзаПС). 3 цієї позиції на основі здійсненого вище аналізу поняття «навчально-методичне забезпечення української мови за професійним спрямуванням» отримує таке трактування: це комплекс навчально-методичних документів, призначених для оптимізації взаємодії викладача і студента у процесі вивчення курсу “УМзаПС”, обгрунтування, перевірки й практичної реалізації методичної системи навчання дисципліни з метою формування визначених компетентностей.

Враховуючи необхідність максимально повного надання студентам актуальної наукової інформації та матеріалів для ефективного опанування курсу "УМзаПС" розробляються інші форми методичного забезпечення дисципліни, зокрема: посібники; методичні вказівки і рекомендації; конспекти лекцій; завдання для самостійної та індивідуальної роботи, ілюстративні матеріали, хрестоматії, каталоги ресурсів, навчальнометодичні комплекси тощо [15]. Важливо зазначити, що необхідність створення навчальнометодичного комплексу дисципліни зумовлюється вимогами конкретного 3ВО і не передбачена жодним нормативним документом.

Мета статті - дослідження змістового наповнення посібників у контексті їх профільної адаптації до компетентнісної парадигми освітніх програм.

Виклад основного матеріалу. “Змістовий компонент підготовки фахівців передбачає чітке окреслення комплексу знань, який має бути засвоєний у процесі вивчення окремих навчальних дисциплін" [14, 19]. Тому аналіз наявних навчально-методичних розробок щодо оптимізації процесу навчання УМзаПС у сучасних педагогічних $3 \mathrm{BO}$ здійснено за такими показниками: 1) змістове забезпечення курсу відповідно до робочої програми; 2) актуальність і новизна вміщеної інформації; 3) відповідність практичного блоку теоретичному наповненню; 4) засоби професійної адаптації базового матеріалу; 5) реалізація компетентнісної парадигми дисципліни.

Загальний огляд змісту навчальних посібників, які рекомендовані та функціонують в освітньому процесі педагогічних 3ВО України, показав їх відповідність затвердженому змістовому наповненню УМзаПС і тенденційність щодо першого базового підручника "Українська мова за професійним спрямуванням”, створеного 2011 р. на основі затвердженої типової програми дисципліни (автори: С. Шевчук, I. Клименко). Зокрема, у рекомендованому Вінницьким державним педагогічним університетом імені М. Коцюбинського навчальному посібнику для самостійної роботи студентів [1] чітко дотримано визначеного у типовій програмі вектору навчання. Однак тематичний розподіл матеріалу здійснено з акцентом на практичні заняття, оскільки для них відведено 24 год, а на лекції - 18 год. Посібник структуровано відповідно до кредитно-модульної системи навчання, доповнено завданнями для самостійної роботи, модульного контролю. Додатки вміщують критерії оцінювання знань студентів, рівні для визначення ступеня засвоєння навчального матеріалу та словник найуживаніших термінів. Другий змістовий модуль, важчий для засвоєння, автори доповнюють окремим навчально-методичним посібником, орієнтованим на діяльнісне опанування особливостей усної та писемної професійної комунікації [11]. Специфікою видання $є$ розкриття особливостей організації навчального процесу за вимогами кредитнотрансферної системи, що реалізована через подання орієнтовної структури залікового кредиту, створення навчально-методичної карти дисципліни та порядку розрахунку рейтингових 


\section{НАВЧАЛЬНО-МЕТОДИЧНЕ ЗАБЕЗПЕЧЕННЯ УКРАЇНСЬКОӤ МОВИЗА}

\section{ПРОФЕСІЙНИМ СПРЯМУВАННЯМ: ВЕКТОР ПРОФІЛЬНОЇ АДАПТАЦІЇ}

балів за видами модульного контролю. Окремим розділом подано тестові завдання для самоконтролю і взаємоперевірки, що значно підвищує цінність видання щодо організації самостійної роботи студентів.

Цікавим з методичного погляду вважаємо посібник-практикум Ж. Колоїз і Н. БерезовськоїСавчук, рекомендований у Криворізькому державному педагогічному університеті [4]. Посібник укладено відповідно до освітньої програми підготовки бакалавра спеціальностей 014.02 - 014.14 Середня освіта, 015.16 Професійна освіта, 022 Дизайн; 024 Хореографія; 242 Туризм, структура й зміст його більш деталізовані, зокрема в блоці 2 "Культура писемного професійного спілкування в аспекті документування", який вмішує 10 тем, присвячених вивченню культури документування різних видів текстів. Однак ні для теоретичної, ні для практичної частин посібника не характерна чітка профілізація, а отже, він легко може бути адаптованим до вивчення УМзаПС студентами будь-якої спеціальності.

Спробу профільної адаптації зробили автори посібника "Українська мова за професійним спрямуванням: теорія і практика" [6] у Національному педагогічному університеті ім. М. Драгоманова. Зміст видання повністю забезпечує курс “УМзаПС” відповідно до робочої програми. Однак акцент у ньому зміщено в лінгвістичному напрямі. На вивчення загальних характеристик української літературної мови і професійного спілкування та документів у професійному мовленні відведено тільки 2 год. Зрозуміло, що грунтовно донести до студентів настільки складний і значний за обсягом матеріал за одне заняття неможливо. Водночас наступні 7 тем повністю дублюють матеріал курсу “Сучасна українська мова з практикумом”, на вивчення якого в згаданому 3ВО (013 Початкова освіта) відведено аж 15 кредитів ECTS [10]. Така ситуація можлива за умови досконалого володіння студентами мовознавчим матеріалом, що дало б можливість розкривати специфіку застосування кожного мовного явища в професійному спілкуванні. Однак практика доводить, що лінгвістична компетентність студентів 1 курсу (у робочій програмі та освітній програмі -1-й семестр) потребує значного вдосконалення, робота над яким займає весь відведений час. Спільна теоретична частина для студентів усіх спеціальностей, оскільки мовні норми не залежать від майбутнього фаху, реалізується в практичному блоці з орієнтацією на професійний контекст. Як стверджують автори, “ремарки ПС-психологія;
ОМ - образотворче мистецтво; ЗЛ - здоров'я людини; ДО - дошкільна освіта є підказкою для викладача і студентів при виборі завдань для виконання, однак вони чисто умовні, оскільки тексти з психології можуть зацікавити, наприклад, образотворців, а тексти зі сфери мистецтва будуть цікавими для педагогів, психологів, валеологів, дошкільників" [6]. Такий спосіб профілізації базового матеріалу на сьогодні залишається поки що єдиною спробою стосовно УМзаПС у педагогічних 3ВО, що підкреслює своєрідність аналізованого видання.

Схожим за структурою, також лінгвістично орієнтованим, $є$ посібник 3. Мацюк, Н. Станкевич [7], рекомендований у робочій програмі УМзаПС Львівського національного університету ім. І. Франка. Призначений для “майбутніх фахівців банківської, фінансової, економіч-ної, юридичної та інших галузей” $[7,2]$, аналізований посібник містить окремі елементи економічного спрямування, переважно приклади речень чи зразки бібліографічного оформлення джерел, які не можна вважати елементами профілізації з огляду на їх незначну кількість. Практичний блок обмежений до планів занять та списків літератури, а завдання для самостійної роботи студентів орієнтовані на знаннєву освітню парадигму (наприклад, опрацювати відповідну літературу, повторити, закріпити зазначені правила, законспектувати та ін.).

В Ужгородському національному університеті рекомендовано методичні розробки до практичних занять з УМзаПС, у яких акцент зроблено на професійній комунікації, зокрема культурі усного спілкування та оформленні ділових паперів [2]. Лінгвістичний аспект у структурі посібника не відображено.

Поєднання лінгвістичної та документної складових дисципліни з переорієнтуванням на компетентнісну освітню парадигму становлять методичну концепцію Н. Юрійчук [16]. Однак значний обсяг інформації та невідповідна йому кількість годин, відведених на його опанування, спричинили логічний хаос у тематичній організації матеріалу і відсутність семантичного зв'язку між темами й питаннями плану до них. Наприклад, прикметник і займенник як частини мови, договір, трудова угода і телеграма розглядаються під заголовком “Мова і професія”. А тема “Стилістичне використання морфологічних засобів мови” об’єднує вивчення прес-релізу, службових записок, числівника як частини мови, дієслова та його форм і правопис часток. Такий розрив між напрямками роботи в межах однієі теми не може забезпечити формування 


\section{НАВЧАЛЬНО-МЕТОДИЧНЕ ЗАБЕЗПЕЧЕННЯ УКРАЇНСЬКОЇ МОВИЗА ПРОФЕСІЙНИМ СПРЯМУВАННЯМ: ВЕКТОР ПРОФІЛЬНОЇ АДАПТАЦЇ̈}

необхідних компетентностей і досягнення запланованих результатів навчання, оскільки не дозволяє встановити взаємозв'язок між мовними явищами та реальним процесом їх функціонування у професійному мовленні, тобто позбавляє навчання діяльнісного компонента.

Якщо більшість аналізованих посібників відображають змістове наповнення УМзаПС, то першою спробою організації напрацювань 3 методики навчання курсу можна вважати посібник Т. Крашеніннікової та А. Подворчан, метою якого визначено опис основних методів та форм навчання $з$ акцентом на нестандартних заняттях [5]. I хоча видання призначене як викладачам, так і студентам, очевидним $є$ його лінгводидактичне позиціонування, що вказує на необхідність таких розробок у контексті нової галузі - методики навчання української мови за професійним спрямуванням.

Висновки. Аналіз навчально-методичних посібників з УМзаПС, призначених для студентів ЗВО, виявив проблемні аспекти в їх змістовій організації, що відображають актуальні питання методики навчання цієї дисципліни. По-перше зміст посібників, рекомендованих і Міністерством освіти та науки України, і рішеннями вчених рад 3ВО, відображає методичні пошуки способів урівноваження лінгвістичного та професійнокомунікативного блоків у структурі УМзаПС. Більшість видань спираються на типову програму курсу та, відповідно, базовий підручник (С. Шевчук, I. Клименко), створений на їі основі. Однак ефективне формування професійно-комунікативних умінь в усному й писемному виявах завжди грунтується на лінгвістичній компетентності студентів. А цей вектор освітньої діяльності потребує додаткових зусиль у ЗВО, оскільки, як показує практика, шкільний рівень знань 3 української мови не здатний забезпечити належної основи для якісної професійної комунікації. Вихід із ситуації, що склалася, вбачаємо в кількох важливих організаційно-методичнихзаходах: 1)введенні курсу “Сучасна українська мова з практикумом” на тих спеціальностях, де його немає; 2) викладанні дисципліни "УМзаПС" на 2-3-у курсах бакалаврату, а не на першому, як відображено в ОП багатьох ЗВО [8; 9; 10]; 3) закріпленні екзамену як підсумкового контролю навчальних досягнень студентів, що підвищить їх мотивацію до самопідготовки та самоконтролю. По-друге, проблемним аспектом у сучасних підручниках і посібниках з УМзаПС вважаємо універсальність їх змісту, іноді - формальну профільну адаптацію (вказівка в анотації, переформулювання тем), яка не має реального впливу на способи і засоби реалізації визначених цілей та досягнення очікуваних результатів.

У контексті з'ясованої проблеми виникає необхідність дослідження понять “профілізація навчання", "профілізація навчальної дисципліни”, а відтак визначення реальних і потенційних способів профілізації, які знаходять відображення в навчально-методичному забезпеченні УМзаПС, що формує перспективний напрям для подальших наукових студій.

\section{ЛIТЕРАТУРА}

1. Богатько В. В., Прокопчук Л. В. Украӥнська мова (за професійним спрямуванням): навчальний посібник для самостійноїроботистудентів. Вінниця: ФОПКорзун Д.Ю., $2012.246 \mathrm{c}$

2. Вегеш А. Українська мова за професійним спрямуванням. Професійна комунікація. Методичні розробки до практичних занять для студентів II курсу гуманітарного напрямку. Ужгород, 2014. 45 с.

3. Вітвицька С. С. Педагогічна підготовка магістрів в умовах ступеневої освіти: теоретико-методологічний аспект: монографія. Житомир: Вид-во ЖДУ імені I. Франка, 2009. 440 c

4. Колоїз Ж. В., Березовська-Савчук Н. А. Українська мова професійного спілкування в аспекті теорії стилів та культури мовлення: практикум. Кривий Ріг: ФОП Маринченко С. В., 2019. 131 с.

5. Крашеніннікова Т.В., Подворчан А.З. Українська мова професійного спрямування (нестандартні заняття): навчальний посібник. Дніпро. 2018. 66 с.

6. Литвин Л.П., Семеренко Г.В. Українська мова за професійним спрямуванням: теорія і практика: навч. посібн. Тернопіль, 2015. $424 \mathrm{c}$.

7. Мацюк 3, Станкевич Н. Українська мова професійного спілкування: навч. посібн. Київ: Каравела, 2005.352 c.

8. Освітньо-професійна програма “Дошкільна освіта. Початкова освіта”. 012 Дошкільна освіта. 01 Освіта / Педагогіка. Вінниця. 2019. 24 с. URL: http:// www.vspu.edu.ua/faculty/pochat/pochat kafmetod/doc/ o3.pdf (дата звернення: 16.03.2021).

9. Освітньо-професійна програма "Початкова освіта. Дошкільна освіта”. 013 Початкова освіта. 01 Освіта / Педагогіка. Умань. 2020. URL: https://fpo.udpu.edu.ua/ images/2020/opp2020/bakal/doscbak310pdf.pdf (дата звернення: 16.03.2021).

10. Освітньо-професійна програма "Початкова освіта та іноземна мова”. 013 Початкова освіта. 01 Освіта / Педагогіка. Національний педагогічний університет імені М. П. Драгоманова. Київ, 2018. 29 с.

11. Прокопчук Л. В., Савчук Т. В. Українська мова за професійним спрямуванням. Професійна комунікація: навчальний посібник. Вінниця: ТОВ “Нілан-ЛТД”, 2014. 205 с.

12. Хабарова, Н. Г. Научно-методическое обеспечение деятельностно-личностной технологии обучения специальной дисциплине “Анализ финансово-хозяйственной деятельности” в ССУЗ: дисс. ... канд. пед. наук: 13.00.02. Казань, 2007. 203 с. 


\section{НАВЧАЛЬНО-МЕТОДИЧНЕ ЗАБЕЗПЕЧЕННЯ УКРАЇНСЬКОЇ МОВИЗА ПРОФЕСІЙНИМ СПРЯМУВАННЯМ: ВЕКТОР ПРОФІЛЬНОЇ АДАПТАЦІЇ}

13. Чертопятова А. С., Ракова О. А. Теоретикометодологические аспекты разработки научнометодического обеспечения дисциплин вариативного экономического модуля. Перспективы науки и образования. 2019. №3 (39). C. 210-226.https://doi: 10.32744/pse.2019.3.16

14. Шквир О., Гайдамашко І. Підготовка майбутніх учителів початкової школи до дистанційного навчання. Молодь і ринок. 2020. № 3-4 (182-183), С. 17-22.

15. Щодо рекомендацій з навчально-методичного забезпечення. Лист Міністерства освіти і науки України від 09.07.2018 № 1/9-434. URL: https://mon.gov.ua/ua/npa/ list-mon-19-434-vid-09072018-roku-shodo-rekomendacij-znavchalno-metodichnogo-zabezpechennya (дата звернення: 15.03.2021).

16. Юрійчук Н. Д. Українська мова (за професійним спрямуванням). Навчально-методичний посібник для студентів закладів вищої освіти. ПереяславХмельницький: Домбровська Я. М. 2020. 166 с.

\section{REFERENCES}

1. Bohatko, V. V. \& Prokopchuk, L. V. (2012). Ukrainska mova (za profesiinym spriamuvanniam): navchalnyi posibnyk dlia samostiinoi roboty studentiv [Ukrainian language (for professional purposes): a textbook for independent work of students]. Vinnytsia, 246 p. [in Ukrainian].

2. Vehesh, A. (2014). Ukrainska mova za profesiinym spriamuvanniam. Profesiina komunikatsiia. Metodychni rozrobky do praktychnykh zaniat dlia studentiv II kursu humanitarnoho napriamku [Ukrainian language for professional purposes. Professional communication. Methodical developments for practical classes for secondyear students of the humanities]. Uzhhorod, $45 \mathrm{p}$. [in Ukrainian].

3. Vitvytska, S. S. (2009). Pedahohichna pidhotovka mahistriv v umovakh stupenevoi osvity: teoretykometodolohichnyi aspekt: monohrafiia [Pedagogical training of masters in the conditions of degree education: theoretical and methodological aspect: monograph]. Zhytomyr, 440 p. [in Ukrainian].

4. Koloiz, Zh. V. \& Berezovska-Savchuk, N. A. (2019). Ukrainska mova profesiinoho spilkuvannia $\mathrm{v}$ aspekti teorii styliv ta kultury movlennia: praktykum [Ukrainian language of professional communication in the aspect of theory of styles and culture of speech: practicum]. Kryvyi Rih, 131 p. [in Ukrainian].

5. Krasheninnikova, T. V. \& Podvorchan, A. Z. (2018). Ukrainska mova profesiinoho spriamuvannia (nestandartni zaniattia): Navchalnyi posibnyk [Ukrainian language of professional orientation (non-standard classes): textbook]. Dnipro, 66 p. [in Ukrainian].

6. Lytvyn, L. P. \& Semerenko, H. V. (2015). Ukrainska mova za profesiinym spriamuvanniam: teoriia i praktyka: navch. posibn. [Ukrainian language for professional purposes: theory and practice: textbook]. Ternopil, $424 \mathrm{p}$. [in Ukrainian].

7. Matsiuk, Z. \& Stankevych, N. (2005). Ukrainska mova profesiinoho spilkuvannia: navch. posibn. [Ukrainian language of professional communication: textbook]. Kyiv, 352 p. [in Ukrainian].

8. Osvitno-profesiina prohrama "Doshkilna osvita. Pochatkova osvita”. 012 Doshkilna osvita. 01 Osvita / Pedahohika (2019). [Educational and professional program
"Preschool education. Primary education". 012 Preschool education. 01 Education/Pedagogy]. Vinnytsia, 24 p. Available at: http://www.vspu.edu.ua/ faculty/pochat/pochat kafmetod/ doc/o3.pdf(Accessed 16 Mar. 2021). [in Ukrainian].

9. Osvitno-profesiina prohrama "Pochatkova osvita. Doshkilna osvita". 013 Pochatkova osvita. 01 Osvita / Pedahohika (2020). [Educational and professional program "Primary education. Pre-school education". 013 Primary education. 01 Education / Pedagogy]. Uman. Available at: https://fpo.udpu.edu.ua/images/2020/ opp2020/bakal/ doscbak310pdf.pdf(Accessed 16 Mar. 2021). [in Ukrainian].

10. Osvitno-profesiina prohrama "Pochatkova osvita ta inozemna mova". 013 Pochatkova osvita. 01 Osvita / Pedahohik. (2018). [Educational and professional program "Primary education and foreign language". 013 Primary education. 01 Education / Pedagogy]. M.P. Drahomanov National Pedagogical University. Kyiv, 29 p. [in Ukrainian].

11. Prokopchuk, L. V. \& Savchuk, T. V. (2014). Ukrainska mova za profesiinym spriamuvanniam. Profesiina komunikatsiia: navchalnyi posibnyk [Ukrainian language for professional purposes. Professional communication: a textbook]. Vinnytsia, 205 p. [in Ukrainian].

12. Khabarova, N. G. (2007). Nauchno-metodicheskoe obespechenie deyatelnostno-lichnostnoy tekhnologii obucheniya spetsialnoy distsipline "Analiz finansovokhozyaystvennoy deyatelnosti" v SSUZ [Scientific and methodological support of the activity-personal technology of teaching the special discipline "Analysis of financial and economic activities" in the secondary school]. Candidate's thesis. Kazan, 203 p. [in Russian].

13. Chertopyatova, A. S. \& Rakova, O. A. (2019). Teoretiko-metodologicheskie aspekty razrabotki nauchnometodicheskogo obespecheniya distsiplin variativnogo ekonomicheskogo modulya [Theoretical and methodological aspects of the development of scientific and methodological support for the disciplines of the variable economic module]. Prospects for Science and Education. No. 3 (39). pp. 210-226. https://doi: 10.32744/ pse.2019.3.16 [in Russian].

14. Shkvyr, O. \& Haidamashko, I. (2020). Pidhotovka maibutnikh uchyteliv pochatkovoi shkoly do dystantsiinoho navchannia [Preparation of future primary school teachers for distance learning]. Youth \& market. No. 3-4 (182-183), pp. 17-22. [in Ukrainian].

15. Shchodo rekomendatsii z navchalno-metodychnoho zabezpechennia. [Regarding the recommendations for educational and methodological support]. Letter from the Ministry of Education and Science of Ukraine from 09.07.2018 No. 1/9-434. Available at: https://mon.gov.ua/ua/ npa/list-mon-19-434-vid-09072018-roku-shodorekomendacij-z-navchalno-metodichnogo-zabezpechennya (Accessed 15 Mar. 2021). [in Ukrainian].

16. Yuriichuk, N. D. (2020). Ukrainska mova (za profesiinym spriamuvanniam). Navchalno-metodychnyi posibnyk dlia studentiv zakladiv vyshchoi osvity [Ukrainian language (for professional purposes). Educational and methodical manual for students of higher education institutions]. Pereiaslav-Khmelnytsky, $166 \mathrm{p}$. [in Ukrainian].

Стаття надійшла до редакції 16.02.2021 